Gladia Renata Putri ${ }^{1}$, Moses Glorino Rumambo Pandin ${ }^{2}$

${ }^{1}$ Faculty of Economics and Business, ${ }^{2}$ Faculty of Humanities, Universitas Airlangga, Surabaya, Indonesia

Jl. Dr. Ir. H. Soekarno, Mulyorejo, Kec. Mulyorejo, City of Surabaya, East Java 60115

gladia.renata.putri-2020@,feb.unair.ac.id and moses.glorino@,fib.unair.ac.id

\title{
Intelligent Character as a Basic Moral of Millenial's Character Education
}

Book Title: Educating Smart Millennial Generation with Character; Author: Anita Lie; Mutiara Andalas, SJ; Marcellinus Andy Rudhito; Tarsisius Sarkim; CB Mulyatno, Pr; Rohandi; Antonius Herujiyanto; Stephanus Suwarsono; B. Widharyanto; Aufridus Atmadi; Doni Koesoema A .; Wuri Soedjatmiko; Luisa Diana Handoyono; Yohanes Harsoyo; Johnsen Treasure; Hongki Julie; Publishers: PT Kanisius and Sanata Dharma University; Published City $\quad$ : Daerah Istimewa Yogyakarta; Edition, year: First, 2020; Number of Pages: 313 Pages; Book Size: 15 cm x 21 cm; ISBN: 978-979-21-6698-9

\section{INTRODUCTION}

The author made this review intending to fulfil the final project of the Pancasila course with Pancasila and the 21st-century millennial generation theme. Pancasila has values in each of its precepts and is the nation's ideology that has officially become the life guide for the Indonesian people.

The book, entitled Educating Millennial Generation, has addressed to Prof. Rama. Dr. Paulus Suparno, SJ, M.S.T. which will be retired in 2020. Not only that, at the moment when the book had launched, it also stated that this book could be a part of educating the millennial generation to become a smart generation and has a noble character.

This book aimed to influence the millennial generation as an effort to advance Indonesia. But in reality, it has shown a contrary habit among millennial generations. There were so many disrespectful events which became an evidence that younger generations are no longer practicing the noble values of Pancasila. This is in accordance with the development of science and technology. This book is not only intended for millennials, but also for educators because educators are also required to improve their teaching preferences so that the current generation is not only intelligent but also has character.

The Intelligent Character as a Basic Moral of Millenial's Character Education book provides some new information about millennial generations that is in accordance with what is happening today. The younger generation who have been instilled since childhood with ethics and morality will have a strong character and adhere to Pancasila as their guide to maintain their existence and identity. In addition, there is also a section where teachers can get information on how to educate students and conduct their character even in this pandemic situations.

The thing that makes Intelligent Character as a Basic Moral of Millenial's Character Education books important to review because it contains several explanations about education which are in accordance with the era of globalization for millenials. In addition, considering that the millennial generation will always follow technological developments, several chapters mentioned tips for educators to carry out intelligent learning for character education.

\section{REVIEW}

This book to Intelligent Character as a Basic Moral of Millenia's Character Education is an offering to Prof. Rama. Dr. Paulus Suparno, SJ, MST who will retire in 2020. As an educator, he has contributed ideas and ideas for educational development through writing or directly through teacher assistance at the launch of the book Educating Smart Millennial Generations with Character on November 7, 2020, in the remarks of the USD Chancellor Drs. Johana Eka Priyatma, PhD, said that the book that was launched could educate the millennial generation to become a generation that is smart and has character. He also said that we all have to live in a world of education in the pandemic era.

The book entitled Intelligent Character as a Basic Moral of Millenia's Character Education can meet the needs of readers because it invites all of us, especially the millennial generation and educators, 
to take advantage of the current pandemic era to reconstruct and reflect on education in the mind to educate.

This book consists of four parts. The first part discusses developing competencies needed by future generations to optimize various methods and utilize technology in learning. The second part contains approaches or learning models in schools that develop students' sense, power, reasoning, and creativity optimally. The third part presents an article regarding the basic concepts/nature of character education and its possible implementation in various educational activities in schools. The fourth part discusses teacher struggles in terms of competency development and mentoring of students.

The authors hope that the ideas presented inside the book will trigger discussions so that the learning process among educators will continue and be more responsive to the times for optimal development for students.

The book the author reviewed was published in 2020 so that its contents also adjust to the conditions that have occurred recently. The book influences readers because over time, education in Indonesia will follow the development of science and technology so that the millennial generation and educators are able to adapt to it.

Education, in essence, is an effort to make changes to individuals, which are expected to change society for the better. This is because education can change a person. But the situation today is very different. The current situation will be difficult to understand, and the future will be very difficult to predict. The world of education is currently under very strong pressure. The main cause of the pressure that is being experienced today is the demand for change due to advances in technology and communication, as well as the Covid-19 pandemic. The development of information and communication technology and the pandemic brought rapid changes. In the world of education, the source of change can be identified through four main channels or channels, namely first, the main subject of students, namely students; second, the community as the party who enjoys the results of education; third, the community where the educational process occurs; and fourth, are various technologies that support the educational process.

As the main subject in the educational process, students have characteristics that change from time to time. Various names have been known, such as generation X, baby boomers, generation Y, generation Z, and the millennial generation. Each generation group has different characteristics. Included in these characteristics are ideals, lifestyle, and interests and learning styles. These changes require the education system to change so that the education provided to each generation can answer the expectations and development needs of students.

With the Covid-19 virus currently occurring, the millennial generation must feel a tremendous impact on the world of education. When an area has been exposed to the virus, the teaching and learning process in classrooms in that area will have to be stopped and turned into teaching and learning activities at home. This policy to study at home makes teachers/lecturers teach through distance learning using information technology. Students and students access teaching materials provided by teachers/lecturers, teach various assignments, and collect them through their information media. The situation during the Covid-19 pandemic was, of course, unimaginable beforehand, so that almost every teacher or student was not ready to live it. Apart from bringing about various problems, this pandemic also presents new challenges and opportunities in developing education that integrates IT.

Integrating IT into learning at all levels of education can present a new paradigm in learning, namely the paradigm of "Smart Learning." As a new educational Paradigm, smart learning has its foundation on smart devices and smart technology. IT is carried out to provide flexibility in learning, and devices (computers and smartphones) are used as media to access learning content.

Several things are taken into consideration both in the learning design and in its implementation. First, present the influence that creates students' curiosity. Second, presenting smart learning scenarios. Third, provide an introduction (preview) of teaching materials intelligently. Fourth, intelligent response in the learning process. 
The book entitled Intelligent Character as a Basic Moral of Millenia's Character Education also discusses character education in the Free Learning Era. Character education policies and praxis entered a new phase with Nadiem Makarim as the current Minister of Education and Culture. According to Nadiem, character surveys are basically to understand the welfare of students. In flashback, the development of character education policies has experienced fluctuating dynamics. However, day by day, this character education policy is increasingly finding its form. Even though the implementation in education units has not been satisfactory, through the active involvement of many parties in disseminating discourses and various character education praxis, the public increasingly understands and realizes the importance of strengthening noble values in character education.

The issuance of Regulation of the Minister of Education Number 22 of 2020 concerning the Strategic Plan of the Ministry of Education and Culture 2020-2024 indicates that the character survey appears to be directed at the Pancasila Student Profile, namely lifelong students who have global competence and behave according to Pancasila values. This survey holistically measures student growth and development, including respect for differences, collaboration skills, interest and concern for social issues. This survey aims to assess and evaluate the school climate.

Character Education in the Free Era of learning is described in part 3 of the book which is located on pages 183 to 202. And explains the basic concept / essence of character education and its possible implementation in various educational activities in schools. Character Education is not the same as a character survey. The survey only examines the condition and situation of a school, its environment and climate. However, a character survey is a prerequisite for understanding school conditions before designing and implementing a character education movement.

The development of discourse and ideas in transforming education through the Merdeka Learning policy requires several challenges that need to be considered by education actors. First, the school climate is friendly. The first challenge for education units is to create a morally friendly school environment so that students feel comfortable and happy at school. The values in Pancasila, such as cooperation and mutual respect, must be implemented so that there are no gaps or violent and bullying behaviours.

Second, learning is fun. The characteristic of fun learning is based on internal motivation in students to learn without being controlled or supervised. Teachers must learn continuously as part of reflecting on praxis and must also see the shortcomings in teaching. Third, teachers and schools can be trusted. Character education in the Independence Learning era invites teachers to become educators with integrity in the learning process.

Fourth, focus on the quality of learning. In the Free Learning era, the main bill for education services is the result and quality of learning. If character education follows Pancasila values and can run well, the results should be visible, especially in learning outcomes. Fifth, the main challenges after the Covid-19 pandemic. Character education in this new normal era has to consider the role of science and technology in developing a learning culture in schools. Character education, especially for the millennial generation, must begin with respect for each other's lives and education that can lead human life to inventions and innovations to solve problems experienced in life.

Character education based on Pancasila values was in line with technological advances as a major part of every educational process. Character education can have a transformative function in creating a new world that is livable for anyone who lives on this earth, especially the millennial generation, who will be the successors of this earth.

The style, organization, and size are in accordance with the purpose of writing a book, namely follow and live the world of education which is in this pandemic era despite the advancement of science and technology. In addition, the content contained inside the book can be implemented quite easily for millennials and educators. From what has been stated in the contents of the entire book, the authors present a factual and complete study. Parts of the book are also described in accordance with actual situations and according to the target audience. Several advantages from this book is that it has an attractive cover and is brightly coloured to be interested in reading it. The book that author reviewed is 
also published in 2020 so that the phenomena raised, such as the educational discourse of the Free Learning and Covid-19 era, and followed by what is happening now. There are also several authors of this book that readers can read writings from different authors but still in the same chapter or section.

On the other hand, the book entitled Intelligent Character as a Basic Moral of Millenial's Character Education also has some limitations. The words inside the book are difficult to understand so that the reader cannot read at once and requires reading over and over again in order to understand the issues. Moreover, there are only a few pictures, so the readers can get bored easily when reading it, and last, the book doesn't mention any conclusion at the end of each chapter.

Character and moral education, especially for the younger generation or the millennial generation at this time, is very important. Especially when viewed from the current conditions, namely the Covid-19 pandemic, which has made education have a significant change compared to previous years and generations. Suppose before this pandemic, students and students studied offline and interacted with friends and teachers. In that case, it is different when students and students are required to learn online. There is less interaction between peers to shift the values of Pancasila and the value of cooperation and mutual respect. The advancement of science and technology is one of the driving forces for integrating information technology with millennials to adapt education to the current situation. In this book, apart from explaining the education of the Millennial generation, there is also an explanation of intelligent learning and character education. The discourse on character education in the Independence Era of learning conveyed by Nadiem as the minister of education in Indonesia is one way so that the millennial generation can continue to practice the values of Pancasila.

The advice that I can convey to the writer is to use language that is easier to understand and in accordance with the target audience. It would be better if the writers corrected more than once so as to minimize the use of typos. For readers, especially the millennial generation and educators, the writers hoped that this review can be used to implement the values of Pancasila, especially in the face of increasingly technological developments and the existence of a pandemic like these day.

\section{References}

(1) Anggraini D, Fathari F, Anggara WA, et.all. The Practice of Pancasila Values for Millennial Generation. Journal of Social and Political Science Innovation. 2020; 2 (1): 11.

(2) Handitya B. Sowing the Value of Pancasila in the Young Generation of Scholars. Fair Indonesia Journal. 2019; 2 (1): 13.

\section{Authors:}

Prof. Anita Lie, Ed.D. Is a Professor at the Faculty of Teacher Training and Education, Unika Widya Mandala, Surabaya. Her research areas include teacher professional development and language teaching. The results of his research have been published in several international scientific journals. In addition, he also wrote several books and articles on education for the public in mass media such as Kompas and The Jakarta Post.

Mutiara Andalas, SJ, SS, STD alumnus of liceansiat in systematic technology from the Jesuit School of Theology at Berkeley and doctoral in systematic theology. He developed a connection pedagogy for Catholic religious education for generations of $\mathrm{Z}$ and Alpha learners.

Dr. Marcellinus Andy Rudito, S.Pd. lecturer in Mathematics Education, Department of Mathematics and Natural Sciences Education (JPMIPA), Faculty of Teacher Training and Education (FKIP), Sanata Dharma University (USD) Yogyakarta. Has been a lecturer at USD since 1996. He has been active in various teacher training, research, presenters in various national and international seminars as well as a writer in journals in the field of Mathematics and Mathematics Education ..

Drs. Tarsius Sarkim, M. Ed., Ph.D. was born in Kuningan on November 7, 1964. He pursued a Bachelor's degree in the Department of Physics Education at IKIP Sanata Dharma and finished in 1988. Since 1988 he has been a lecturer in the Physics Education study program at Sanata Dharma University. 
Dr. Carolus Borromeus Mulyatno, SS graduated from a bachelor's degree at the Theology Faculty of Sanata Dharma University in 1997 and has been a lecturer at the Theology Faculty of Sanata Dharma University since 1998. In 2008-2014, he was the Chair of the Management of the Basic Education Dynamics Foundation and in 2014- 2024 to become Chairman of the Management of the Basic Education Dynamics Foundation.

Rohandi, Ph.D., is a lecturer in the Physics Education Study Program at Sanata Dharma University and in 1997 he successfully completed his master's program studies at La Trobe University, Melbourne, Australia.

Drs. Antonius Herujiyanto, MA, Ph.D. lecturer at Sanata Dharma University Yogyakarta since 1987 and has the opportunity to teach in Theology, Psychology, PBI, KBI and MPBSI. His main works are al Katresnanism Theory in 2006 and Understanding Indonesian Plays; Wayang and Brechtian Strategy in 2016. He also has a hobby of writing as a journalist and correspondence for the BBC-M, Caversham, UK from 2001 to 2019.

Prof. Dr. Stephanus Suwarsono became lecturer at Sanata Dharma University in Yogyakarta since 1975 support Mathematics Education and became a professor in the field of Mathematics Education at Sanata Dharma University in 2008.

Dr. B. Widharyanto, M.Pd. studied undergraduate degree in 984-1989 at the Indonesian Language and Literature Education Study Program, FPBS, IKIP Sanata Dharma Yogyakarta. He has been a lecturer from 1995-2016 in the Indonesian Language and Literature Education Study Program and since 2016 until now he has been a lecturer in the Indonesian Language and Literature Education Masters Study Program.

Drs. Aufridus Atmadi, M.Si. born on May 151960 in Sragen. He is currently a lecturer at Sanata Dharma University in the Physics Education Study Program and the focus of his work is Inquiry-Based Physics Learning Methods.

Doni Koesoema A., M.Ed is now a lecturer at Multimedia Nusantara University, Serpong, and is a member of the National Education Standards Agency for the period 2019-2023.

Prof. Dr. Wuri Soedjatmiko is a Professor at the Master of English Language Education (MPBI), Postgraduate School, Widya Mandala Catholic University, Surabaya. He is the editor-in-chief of Beyond Words Online Journal, the scientific journal MPBI.

Dr. Luisa Diana Handoyo was born on July 29, 1981 in Tangerang and since 2009 until now she has been teaching at the Biology Education Study Program, FKIP, Sanata Dharma University Yogyakarta.

Dr. Yohanes Harsoyo, S.Pd., M.Si was born in Sleman on January 25, 1971. Graduated with a Bachelor of Economics from Sanata Dharma University in 1994 and is currently pursuing economic education.

Johnsen Harta, M.Pd is a lecturer in the Chemistry Education Study Program at Sanata Dharma University, Yogyakarta and is currently working in the field of evaluation in Chemistry learning and Innovative Chemistry learning method models.

Dr. Hongki Julie, M.Sc. born on November 17, 1975 in Jakarta and is an alumnus of the Mathematics Education Study Program at Sanata Dharma University. He succeeded in publishing two textbooks in 2017 with the title Introduction to Opportunity Theory and Junior High School Mathematics Learning. 